УДК 664.8.047:621.577

\title{
АНАЛІЗ ЕНЕРГЕТИЧНИХ ПОКАЗНИКІВ ПРОЦЕСУ ТЕПЛОНАСОСНОГО СУШІННЯ
}

\author{
Снсжкін Ю.Ф., член-кореспондент НАН України, Чалаєв Д.М., канд. техн. наук, \\ Дабіжа Н.О., канд. техн. наук
}

Інститут технічної теплофізики НАН Украӥни, вул. Желябова, 2а, Київ, 03680, Україна

Розглянуті процеси видалення вологи 3 теплоносія під час теплонасосного сушіння. Досліджено вплив тепловологісних параметрів теплоносія на енергетичні показники роботи теплового насоса.
Рассмотрены процессы удаления влаги из теплоносителя при теплонасосной сушке. Изучено влияние тепловлажностных параметров теплоносителя на энергетические показатели работы теплового насоса.
The processes of moisture extraction from the heat-carrying agent in heat pump drying are considered. The influence of thermomoist parameters of the heatcarrying agent on energy performance of the heat pump has been studied.

Бібл. 13, рис. 5.

Ключові слова: теплонасосні цикли, теплові насоси, сушіння, енергоефективність.

\section{Bcmyn}

Процеси конвективного сушіння широко застосовуються в агропромисловому комплексі, на підприємствах хімічної, деревопереробної, фармацевтичної та інших галузях промисловості. Термічне зневоднення є одним 3 найбільш енергоємних технологічних процесів i, зважаючи на високу вартість енергоресурсів, в значній мірі визначає економічні показники виробництва. Так, на процеси термічного зневоднення витрачається до $10 \%$ енергії, споживаної в промисловому секторі, тому дослідження спрямовані на раціональне використання енергоресурсів в процесах сушіння є актуальними.

Підвищення ефективності, надійності і безпеки роботи сушильного обладнання може вирішуватись шляхом застосування теплогенеруючих теплонасосних агрегатів, в яких здійснюється примусове осушення відпрацьованого сушильного агента, утилізація теплоти конденсації вилученої вологи та повернення іiі на більш високому температурному рівні в технологічний процес сушіння шляхом застосування теплонасосного циклу.

Традиційні конвективні сушарки за своїми конструктивними особливостям $є$ найбільш пристосованими для інтеграції в сушильний цикл теплового насоса [1]. А відпрацьований сушильний агент є тим видом вторинних енергетичних ресурсів, що слугує низькотемпературним джерелом енергії для теплового насоса.

Розробка конвективних сушильних установок на базі теплових насосів $є$ актуальним напрямком досліджень і розробок у ряді країн світу (Канада, Німеччина, Норвегія, Китай тощо) $[2,3,4]$. Так в публікаціях, присвячених теплонасосному сушінню, викладені результати досліджень щодо ефективності застосування теплових насосів в камерній та тунельній сушарках $[5,6]$, в сушарці з псевдозрідженим шаром [7], у вакуумсублімаційній сушарці [8], запропонована сушарка 3 термохімічним тепловим насосом [9]. Аналіз публікацій показав, що переважна більшість робіт пов'язана із застосуванням парокомпресійних теплових насосів 3 електроприводом для низькотемпературних процесів сушіння через їх найбільше розповсюдження i простоту організації систем з їх використанням.

Однак, на сьогоднішній день широко використовуються тільки теплонасосні установки для сушіння деревини, як найбільш досліджені і прості в управлінні теплонасосний агрегат в цій установці працює в постійному температурному режимі протягом всього процесу сушіння.

Сушіння термолабільних матеріалів (таких, як водорості, лікарські трави, протеїн, фрукти тощо) вимагає більш складного алгоритму управління процесом зневоднення. Для оптимізації енерговитрат теплонасосний агрегат на різних стадіях сушіння повинен працювати в перемінних режимах - протягом циклу сушіння необхідно регулювати як інтенсивність теплопідводу, так і ступінь осушування теплоносія. Широке застосування теплових насосів для конвективного сушіння термолабільних матеріалів стримується недостатньою вивченістю методів оптимізації процесу, що обумовлено нестачею експериментальних даних щодо тепломасообміних процесів, які відбуваються в широкому діапазоні змінювання тепловологісних умов проведення процесу сушіння, і відсутністю узагальнених методик їх чисельного розрахунку.

В процесі теплонасосного сушіння величина поточних енерговитрат значною мірою залежить від вологовмісту сушильного агента i температурного режиму його осушення у випарнику теплового насоса [10, $11,12]$. В зв'язку з цим, дані дослідження спрямовані на оптимізацію температурних режимів роботи теплонасосного агрегату з метою скорочення енерговитрат під час сушіння.

\section{Результати досліджень}

Дослідження проводились для камерних конвективних сушильних установок 3 замкненим контуром циркуляції теплоносія. При цьому теплоносій циркулює по колу, а волога, що вилучається 3 матеріалу, не вино- 
ситься сушильним агентом в оточуюче середовище, а конденсується на холодній поверхні випарника теплового насоса i вилучається в скрапленому вигляді. Така схема роботи сушарки дозволяє використовувати як теплоносій крім повітря інертні гази, а також підтримувати необхідні параметри сушіння незалежно від тепловологісного стану атмосферного повітря.

Схематично конвективна сушарка 3 теплонасосною системою підготовки теплоносія та процес сушіння в $H$-d діаграмі показані на рис. 1.

Робота сушарки здійснюється таким чином. Нагріте у конденсаторі 6 теплового насоса сухе повітря (точка a) надходить до сушильної камери 1, де обдуває візок 2 із продуктом i, відбираючи вологу від продукту, адіабатично зволожується (процес $a-b)$. Після цього зволожене повітря розділяється на два потоки, один iз яких повертається на рециркуляцію, а другий подається в тепловий насос на осушення. Осушуване повітря спочатку частково охолоджується в рекуперативному теплообміннику «повітря-повітря» 5 (процес $b$-c), після чого доохолоджується у випарнику 4 теплового насоса (процес $\left.c-c^{\prime}-d\right)$. При цьому частина вологи, що міститься в повітрі, конденсується, і вода виводиться 3 об'єму сушильної камери. Після проходження через випарник 4 охолоджене й осушене повітря підігрівається в рекуператорі 5 (процес $d$-e) і змішуєть-ся 3 вологим рециркулюючим повітрям (процеси $e-f$ i $b$ - $f$ ). Змішане повітря (точка $f$ ) підігрівається в конденсаторі 6 (процес $f-a)$, і цикл повторюється. Необхідно зазначити, що в процесі теплонасосного сушіння в конденсаторі теплового насоса виділяється більше тепла ніж може бути сприйнято в випарнику. Тому для забезпечення постійної температури сушіння надлишок тепла за допомогою додаткового зовнішнього конденсатора 7 відводиться в оточуюче середовище.
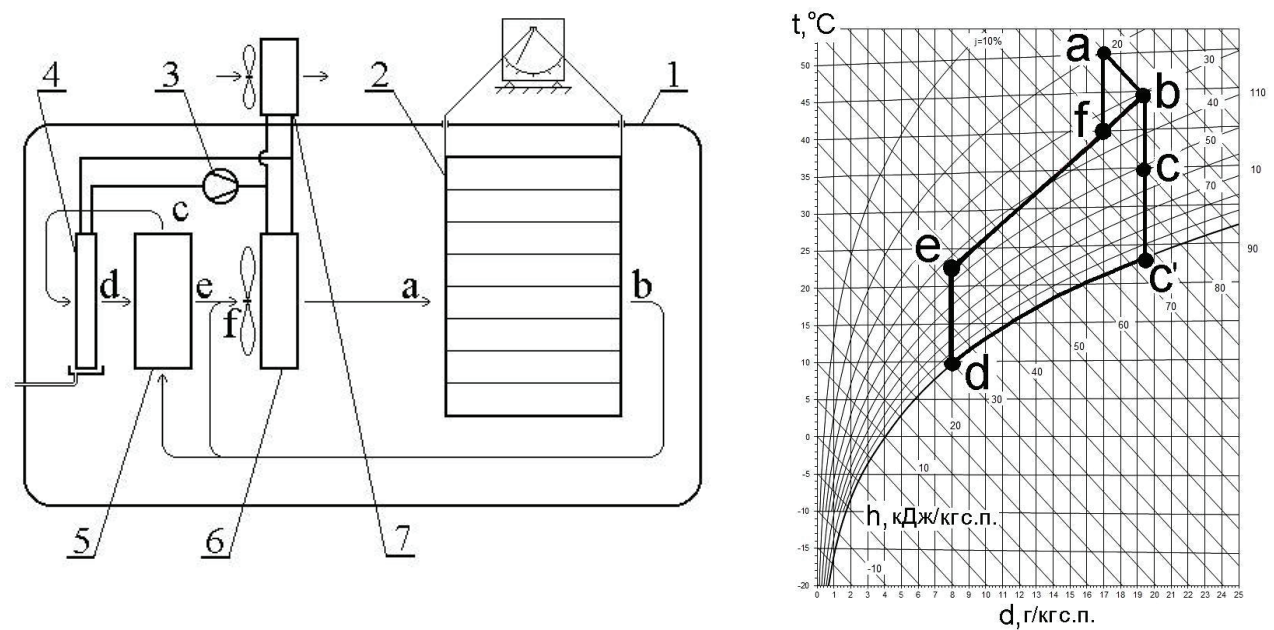

Рис. 1. Теплонасосна конвективна сушильна установка і процес теплонасосного сушіння в

H-d діаграмі: 1 - сушильна камера; 2 - візок; 3 -холодильний компресор; 4 - випарник;

5 -рекуперативний теплообмінник «повітря-повітря»; 6-конденсатор; 7-зовнішній конденсатор.

Для аналізу енергетичних показників та оптимізації процесу сушіння розроблена математична модель розрахунку енерговитрат на зневоднення теплоносія в $H-d$ діаграмі.

В розрахунковій програмі задаються такі вихідні дані: $t_{a}$ - температура теплоносія на вході до сушильної камери; $d_{a}$ - вологовміст теплоносія на вході до сушильної камери, г/кг с.п.; $G_{a}$ - витрата теплоносія, кг с.п.; $t_{b}$ - температура теплоносія на виході з сушильної камери; $t_{d}$ - температура охолодження теплоносія в випарнику теплового насоса; $E$ - ефективність рекуператора.

Параметри теплоносія в інших ключових точках процесу і енергетичні показники теплонасосного циклу розраховуються за наданим алгоритмом.

Розрахункові параметри: $t_{c}$ - температура вологого теплоносія після рекуператора, $t_{e}$ - температура осушеного теплоносія після рекуператора; $t_{f}$ - температура теплоносія після змішання; $d_{b}$ - вологовміст теплоносія на виході з сушильної камери; $d_{d}$ - вологовміст осушеного теплоносія; $d_{f}$ - вологовміст теплоносія після змішання; $H_{-}$- ентальпія теплоносія на вході до сушильної камери; $H^{a}$ - ентальпія вологого теплоносія після рекуператора; $H_{d}^{c}$ - ентальпія осушеного теплоносія; $H_{e}$ - ентальпія осушеного теплоносія після рекуператора; $H_{f}$ - ентальпія теплоносія після змішання; $G_{a-b}$ - витрата теплоносія через сушильну камеру, кг с.п.; $G_{b-c}-$ частка осушуваного теплоносія, кг с.п.; $Q_{o}$ - холодопродуктивність теплового насоса; $Q_{k}$ - теплопродуктивність теплового насоса; $\Delta Q_{\kappa}$ - надлишок теплопродуктивності теплового насоса; $N$ - споживана потужність теплового насоса; $q$ - питомі енерговитрати на видалення вологи.

Розрахункові формули для визначення тепловологісних параметрів в ключових точках процесу (рис. 1):

Точка А $t_{a}$ - задано; $d_{a}$ - задано, г/кг с.п.; $G_{a-b}=1$ кг с.п.; $H_{a}=1,006 \cdot t_{a}+\left(2501+1,85 \cdot t_{a}\right) \cdot \frac{d_{a}}{1000}$, кДж/кг с.п. 
Точка В $t_{b}$-задано; $H_{b}=H_{a}$;

$d_{b}=\frac{1000 \cdot\left(H_{a}-1,006 \cdot t_{b}\right)}{2501+1,85 \cdot t_{b}}$, г/кг с.п.

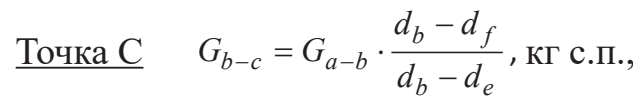

$d_{c}=d_{b}, \quad d_{e}=d_{d}=3,8474 \cdot e^{0,0679 t_{d}}-$ залежність вологовмісту повітря від температури на лінії $\varphi=100 \%$ в інтервалі температур $0 . .20^{\circ} \mathrm{C}$;

$$
\begin{aligned}
& \text { якщо } H_{b}-\left(H_{e}-H_{d}\right)-3,3776 \cdot d_{b}-8,1529 \geq 0, \\
& \text { тоді } t_{c}=\frac{1000 \cdot H_{c}-2501 \cdot d_{c}}{1006+1,85 \cdot d_{c}}, \\
& d_{c}=d_{b}, \quad H_{c}=H_{b}-\left(H_{e}-H_{d}\right),
\end{aligned}
$$

де $H_{c^{\prime}}=3,3776 \cdot d_{b}-8,1529$ - залежність ентальпії від вологовмісту повітря на лінії $\varphi=100 \%$ в інтервалі температур $20 \ldots 30^{\circ} \mathrm{C}$;

$$
\begin{aligned}
& \text { якщо } H_{b}-\left(H_{b}-H_{b}\right) \leq H_{c} \text {, тоді: } \\
& t_{c}=18,128 \cdot \operatorname{Ln}\left(H_{c}\right)-53,562, \\
& d_{c}=0,1594 \cdot H_{c}^{1,1164}, H_{c}=H_{b}-\left(H_{e}-H_{d}\right) .
\end{aligned}
$$

Точка D $\quad t_{d}$-задано; $d_{d}=3,8474 \cdot e^{0,0679 t_{d}}$, г/кг с.п.;

$$
H_{d}=1,006 \cdot t_{d}+\left(2501+1,85 \cdot t_{d}\right) \cdot \frac{d_{d}}{1000}, \text { кДж/кг с.п. }
$$

Точка $\mathrm{E} \quad t_{e}=t_{d}+E \cdot\left(t_{b}-t_{d}\right) ; \quad d_{e}=d_{d} ;$

$$
H_{e}=1,006 \cdot t_{e}+\left(2501+1,85 \cdot t_{e}\right) \cdot \frac{d_{e}}{1000}, \text { кДж/кг с.п. }
$$

$\underline{\text { Точка } \mathrm{F}} \quad t_{f}=\frac{1000 \cdot H_{f}-2501 \cdot d_{f}}{1006+1,85 \cdot d_{f}} ; \quad d_{f}=d_{a}$;

$$
H_{f}=\frac{H_{e} \cdot\left(d_{b}-d_{f}\right)+H_{b} \cdot\left(d_{f}-d_{e}\right)}{d_{b}-d_{e}}, \text { кДж/кг с.п. }
$$

Розрахункові формули для визначення енергетичних показників теплонасосного циклу при витраті теплоносія через сушильну камеру $G_{a-b}$ кг с.п.:

Холодопродуктивність теплового насоса

$$
Q_{o}=G_{b-c} \cdot\left(H_{c}-H_{d}\right)=G_{a-b} \cdot \frac{d_{b}-d_{f}}{d_{h}-d_{e}} \cdot\left(H_{c}-H_{d}\right), \text { кДж. }
$$

Споживана потужність теплового насоса

$$
N=\frac{Q_{o}}{C O P-1}, \text { кДж, }
$$

де $C O P=0,45 \cdot\left(\frac{t_{a}+273}{t_{a}-t_{d}}\right)$ - усереднена величина коефіцієнта перетворення для дійсного циклу парокомпресійних теплових насосів, яка складає $0,45 \ldots 0,50$ COP циклу Карно.
Теплопродуктивність теплового насоса

$Q_{\kappa}=Q_{o}+N$, кДж.

Надлишкова теплопродуктивність теплового насоса

$\Delta Q_{\kappa}=Q_{\kappa}-G_{a-b} \cdot\left(H_{a}-H_{f}\right)$, кДж.

Енерговитрати на видалення вологи:

$q=\frac{1000 \cdot N}{G_{b-c} \cdot\left(d_{c}-d_{d}\right)}$, кДж/кг.

Слід зазначити, що використана в математичній моделі узагальнена формула розрахунку коефіцієнта перетворення $C O P$ дозволяє досить точно визначити величину питомих енерговитрат, але не враховує зміну абсолютної величини тепло- i холодопродуктивності теплового насоса при різних режимах роботи, що впливає на його продуктивність по видаленій волозі. Для визначення впливу режиму сушіння на продуктивність сушильної установки необхідно при виконанні розрахунків використовувати робочу характеристику конкретного застосовуваного холодильного компресора. Наприклад, робоча характеристика холодильного компресора на $R-134 a$ (рис. 2) показує, що при зниженні температури кипіння холодоагенту $315^{\circ} \mathrm{C}$ до $5^{\circ} \mathrm{C}$ його холодопродуктивність i, відповідно, вологовидалення зменшується в 1,5 рази.

Результати розрахункового дослідження впливу тепловологісних параметрів теплоносія та ефективності рекуперативного теплообмінника на енерговитрати на видалення вологи наведені на рис. 3, 4, 5 .

У найбільшій мірі на величину $q$ впливає ступінь вологовмісту осушуваного теплоносія (рис. 3). Це пояснюється тим, що зі зниженням його вологовмісту збільшується доля енергії, яка витрачається непродуктивно на охолодження і нагрівання маси повітря. При осушенні глибше за $d=15$ г/кг с.п. енерговитрати різко зростають, тому при виборі оптимального тепловологісного стану теплоносія необхідно керуватися даними 3 гігротермічної рівноваги та кінетики сушіння певного матеріалу [13].

Важливе значення має також оптимізація температурного режиму процесу сушіння. Зниження температури теплоносія до $45 \ldots 50{ }^{\circ} \mathrm{C}$ дозволяє зменшити поточні енерговитрати практично в два рази (рис. 4), однак при цьому подовжується час сушіння. Тому управління температурою і вологовмістом теплоносія впродовж процесу сушіння має бути організовано таким чином, щоб мінімізувати енерговитрати в розрахунку на весь період сушіння.

Ефективним рішенням, що дозволяє знизити поточні енерговитрати при теплонасосному сушінні та зменшити встановлену потужність теплонасосного агрегату, $€$ рекуперація холоду за допомогою теплообмінника «повітря-повітря». При цьому відпрацьований теплоносій, що надходить на охолодження до випарника теплового насоса, частково охолоджується за рахунок теплообміну з вже охолодженим теплоносієм, що дозволяє в залежності від ефективності рекуператора в $1,5 \ldots 2$ рази зменшити енерговитрати на процес сушіння (рис. 5). 


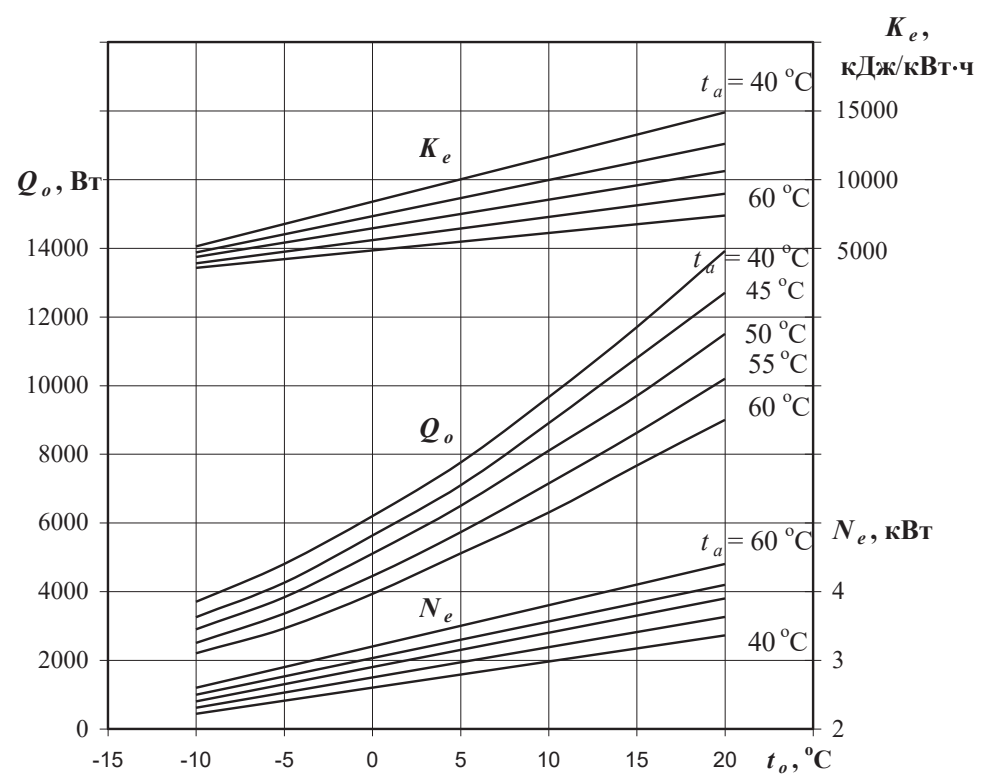

Puс. 2. Характеристика теплонасосного агрегату на робочому тілі R-134a.

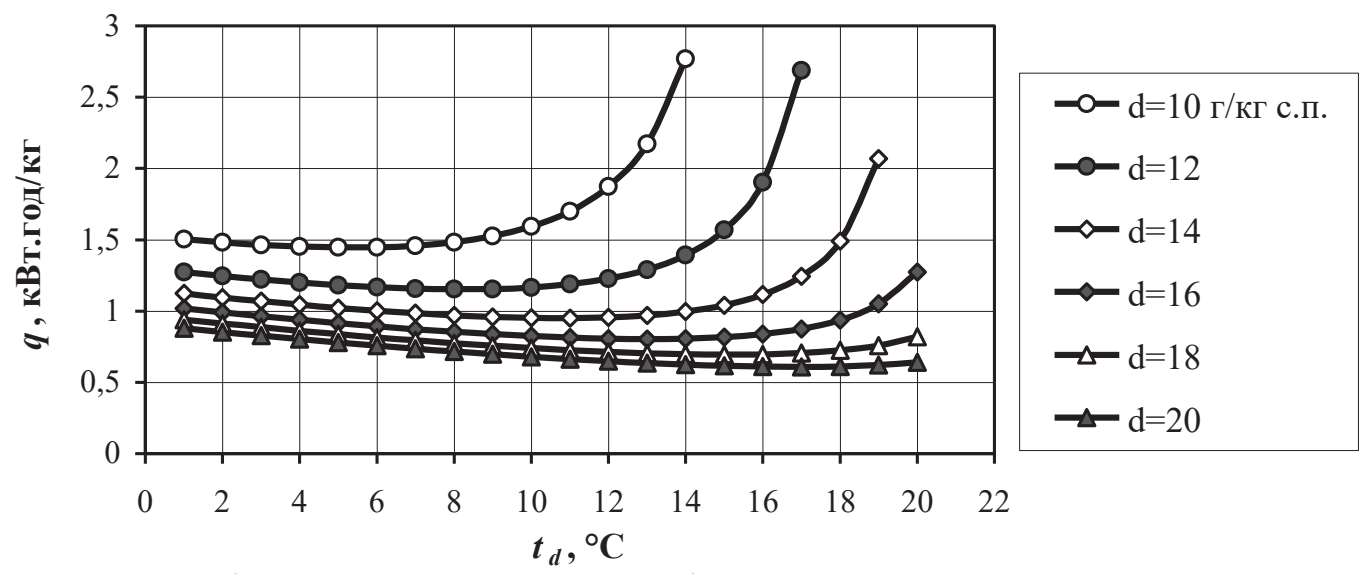

Рис. 3. Вилив вологовмісту осущуваного теплоносія на енерговитрати процесу видалення вологи.

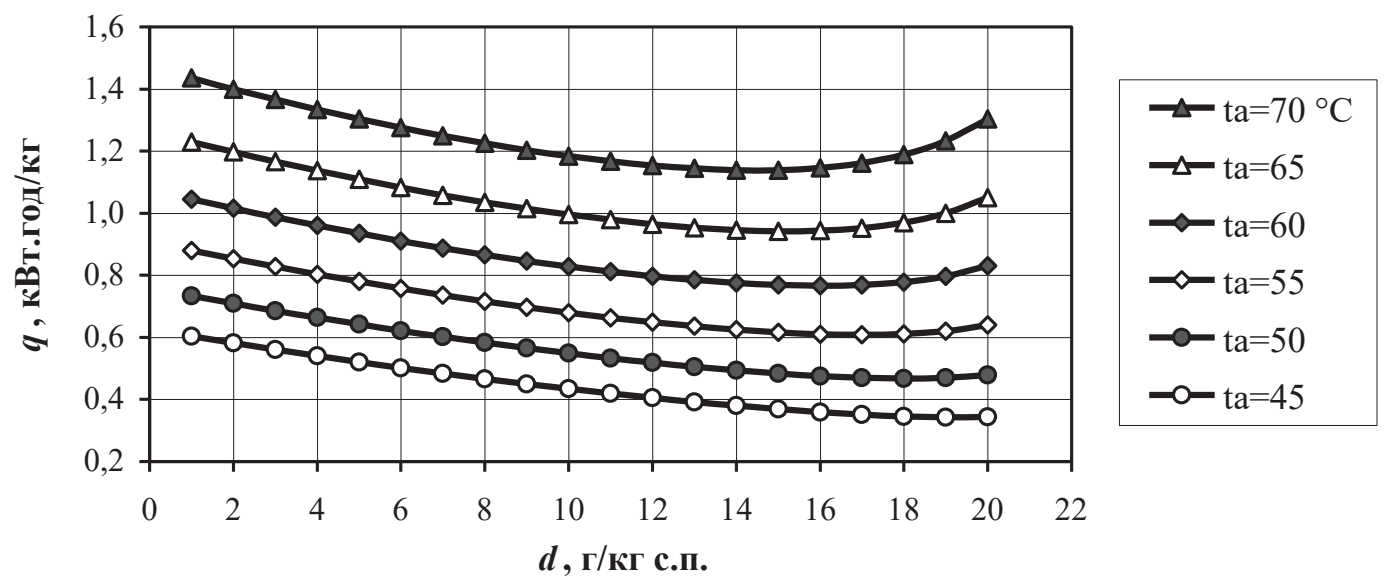

Рис. 4. Вплив температури сушіння на енерговитрати процесу видалення вологи (при ефективності рекуператора $E=0,7$ ). 


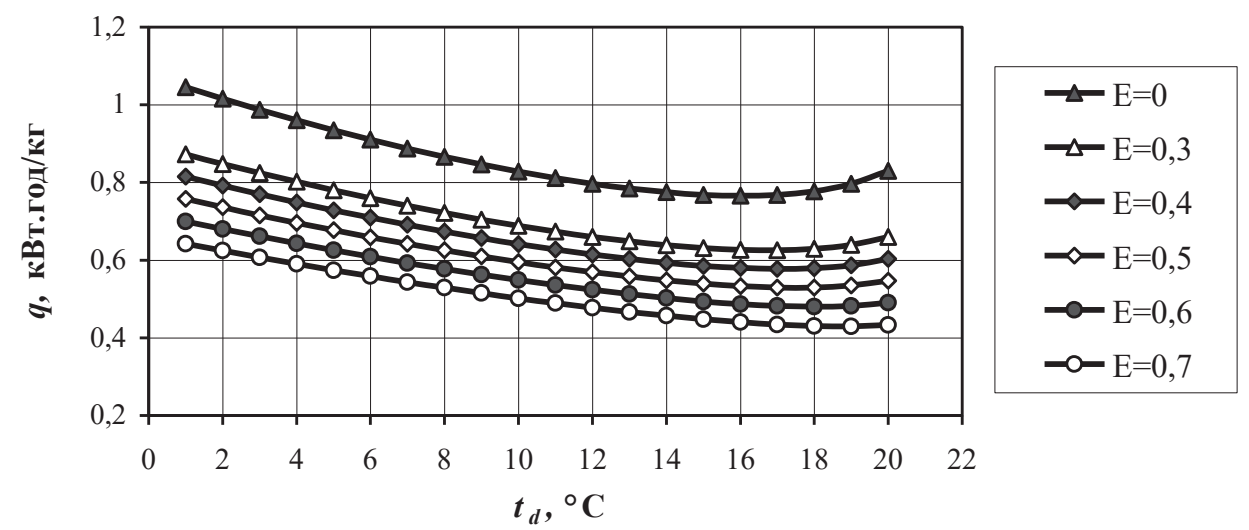

Рис. 5. Залежність енерговитрат на видалення вологи від ефективності рекуператора $E$ (при $t_{a}=60^{\circ} \mathrm{C}$ i $d_{a}=20 \mathrm{z} / \mathrm{K}^{2} \mathrm{c.n}$. .).

Дослідження проводяться в рамках цільової програми наукових досліджень НАН України "Надійність і довговічність матеріалів, конструкцій, обладнання та споруд” (Ресурс-2) (проект Р 5.8).

\section{Висновки}

1. Використання теплових насосів як теплогенераторів в конвективних сушильних установках дозволяє утилізувати теплоту відпрацьованого теплоносія і повернути її в процес сушіння на більш високому температурному рівні. Це дозволяє знизити енерговитрати на процес конвективного сушіння в $1,5 \ldots 2,5$ рази.

2. Для кожного заданого тепловологісного стану сушильного агента відповідно існує оптимальний температурний режим роботи теплового насоса, який забезпечує мінімальні енерговитрати на сушіння.

3. Енерговитрати в процесі теплонасосного сушіння в значній мірі залежать від вологовмісту та температури теплоносія. Чим більше осушується теплоносій, тим вищі енерговитрати на видалення вологи. При осушені глибше за $d=15$ г/кг с.п. енерговитрати різко зростають. Також величина енерговитрат на зневоднення зростає з підвищенням температури сушіння. Тому при застосуванні теплового насоса оптимальні температури сушіння становлять $50 \ldots 55^{\circ} \mathrm{C}$. Застосування рекуперативного теплообмінника дозволяє в залежності від його ефективності в 1,5...2 рази зменшити енерговитрати на процес сушіння.

\section{ЛІТЕРАТУРА}

1. Снєжкін Ю.Ф., Чалаєв Д.М., Шаврін В.С., Шаnap P.O., Хавін О.О., Дабіжа Н.О. Використання теплових насосів в процесах сушіння / Промышленная теплотехника. - 2006. - Т. 28, № 2. - С. 106-110.

2. Kudra T., Mujumdar Arun S. Advanced Drying Technologies. - New York, Basel: Marcel Dekker, Inc., 2002. - 472 c. ISBN: 0-8247-9618-7.

3. Chua K.J., Chou S.K., Mujumdar A.S., Ho J.C., Hawlader M.N.A. Heat pump drying: recent developments and future trends / Drying Technology. - 2002. -V. 20, № 8. - P. 1559-1577.
4. Minea $V$. Drying heat pumps-Part I: System integration / International Journal of Refrigeration. - 2013.№ 36. - P. 643-658.

5. Prasertsan S., Saen-saby P. Heat pump drying of agricultural materials / Drying Technology. - 1998.- V. 16, № $1 \& 2$. - P. 235-250.

6. Chua K.J., Chou S.K. A modular approach to study the performance of a two-stage heat pump system for drying / Applied Thermal Engineering. - 2005. - № 25. - P. 13631379.

7. Alves-Filho O., Strømmen I. The Application of Heat Pump in Drying of Biomaterials / Drying Technology. 1996. - V. 14, № 9. - P. 2061-2090.

8. Artnaseaw A., Theerakulpisut S., Benjapiyaporn C. Development of a vacuum heat pump dryer for drying chilli / Biosystems Engineering. - 2010. - V. 105, № 1. - P. 130138.

9. Ogura H., Ishida H., Kage H., Mujumdar A.S. Enhancement of Energy Efficiency of a Chemical Heat Pump-Assisted Convective Dryer / Drying Technology. 2003. - V. 21. - P. 279-292.

10. Чалаев Д.М., Дабижа Н.А., Шаврин В.С., Хавин А.A. Оптимизация режимов работы теплонасосной конденсационной сушильной установки / Труды 1-й Междунар. научно-практич. конф. "Современные энергосберегающие тепловые технологии (сушка и термовлажностная обработка материалов)". - Москва: 2002. - T. 4. - C.234-236.

11. Снежкин Ю.Ф., Чалаев Д.М., Дабижа Н.А. Обезвоживание коллоидных капиллярно-пористых материалов в условиях высоковлажностной среды / Труды $\mathrm{V}$ Минского междунар. форума по тепло- и массообмену. - Минск: 2004.

12. Снежкин Ю.Ф., Чалаев Д.М., Шаврин В.С., Дабижа Н.А., Гатилов К.А. Эффективность применения тепловых насосов в процессах конвективной сушки / Наукові праці ОНАХТ. - Вип.30. - Т.1. - С. 185-189.

13. Дабижа Н.А. Энергоэффективная технология сушки термолабильных материалов с использованием тепловых насосов / Наукові праці ОНАХТ. - Вип. 39. T. 2. - C. 341-345. 


\section{ANALYSIS OF ENERGY PERFORMANCE OF HEAT PUMP DRYING}

\section{Snezhkin Yu.F., Chalaev D.M., Dabizha N.O.}

Institute of Engineering Thermophysics of the National Academy of Sciences of Ukraine, vul. Zheliabova, 2a, Kyiv, 03680, Ukraine

One of ways to improve the energy efficiency of convective dryers is the use of the energy-saving equipment such as heat pumps. In the process of heat pump drying the amount of current energy consumption largely depends on the moisture content of drying agent and temperature conditions of the moisture extraction in the evaporator of the heat pump. The purpose of the study is optimization of temperature conditions of heat pump unit running to reduce energy consumption during drying. The processes of moisture extraction from the heat-carrying agent in heat pump drying are considered. The influence of thermomoist parameters of the heat-carrying agent on energy performance of the heat pump has been studied.

References 13, figures 5 .

Key words: heat pump cycles, heat pump, drying, energy efficiency.

1. Snezhkin Yu.F., Chalaev D.M., Shavrin V.S., Shapar R.O., Khavin O.O., Dabizha N.O. Vykorystannia teplovykh nasosiv v protsesakh sushinnia [Heat pump application in drying], Promyshlennaia teplotekhnika [Industrial heat engineering], 2006. V. 28. № 2. P. 106-110. (Ukr.)

2. Kudra T., Mujumdar Arun S. Advanced Drying Technologies, New York, Basel: Marcel Dekker, Inc., 2002. $472 \mathrm{p}$.

3. Chua K.J., Chou S.K., Mujumdar A.S., Ho J.C., Hawlader M.N.A. Heat pump drying: recent developments and future trends, Drying Technology, 2002. V. 20. № 8. P. 1559-1577.

4. Minea $V$. Drying heat pumps-Part I: System integration, International Journal of Refrigeration, 2013. № 36. P. 643-658.

5. Prasertsan S., Saen-saby P. Heat pump drying of agricultural materials, Drying Technology, 1998. V. 16. № 1\&2. P. 235-250.
6. Chua K.J., Chou S.K. A modular approach to study the performance of a two-stage heat pump system for drying, Applied Thermal Engineering. 2005. № 25. P. 1363-1379.

7. Alves-Filho O., Strømmen I. The Application of Heat Pump in Drying of Biomaterials, Drying Technology, 1996. V. 14. № 9. P. 2061-2090.

8. Artnaseaw A., Theerakulpisut S., Benjapiyaporn C. Development of a vacuum heat pump dryer for drying chilli, Biosystems Engineering, 2010. V. 105. № 1. P. 130-138.

9. Ogura H., Ishida H., Kage H., Mujumdar A.S. Enhancement of Energy Efficiency of a Chemical Heat Pump-Assisted Convective Dryer, Drying Technology, 2003. V. 21. P. 279-292.

10. Chalaev D.M., Dabizha N.O., Shavrin V.S., Khavin O.O. Optimizatsiia rezhimov raboti teplonasosnoi kondensatsionnoii sushilnoi ustanovki [Optimization of operating modes of heat pump condensation drying unit], Trudi 1-i Mezhdunar. nauchno-praktich. konf. "Sovremennie energosberegaiushchie teplovie tekhnologii (sushka i termovlazhnostnaia obrabotka materialov)" [Proceeding of 1st Int. Sci.-pract. Conf. "Energy-saving Tecnologies for Drying and Hygrothermal Processing"]. Moskva [Moscow], 2002. V. 4. pp. 234-236. (Rus)

11. Snezhkin Yu.F., Chalaev D.M., Dabizha N.O. Obezvozhivanie kolloidnikh kapiliarno-poristikh materialov v usloviiakh visokovlazhnostnoi sredi [Dehydration of colloidal capillary-porous materials under conditions of a high-moisture environment], Trudi V Minskogo mezhdunar. foruma po teplo- i massoobmenu [Proceeding of V Minsk In-ternational Heat and Mass Transfer Forum]. Minsk [Minsk], 2004. (Rus.)

12. Snezhkin Yu.F., Chalaev D.M., Shavrin V.S., Dabizha N.O., Gatilov K.O. Effektivnost primeneniia teplovikh nasosov $\mathrm{v}$ protsessakh konvektivnoi sushki [Efficiency of using heat pumps in convective drying processes], Naukovi pratsi ONAKHT [Scientific Proceedings of ONAFT], 2007. P. 30. V.1. P. 185-189. (Rus.)

13. Dabizha N.O. Energoeffektivnaia tekhnologiia sushki termolabilnikh materialov s ispolzovaniem teplovikh nasosov [Energy-efficient drying technology of thermolabile materials with using heat pumps], Naukovi pratsi ONAKHT [Scientific Proceedings of ONAFT], 2011. S. 39. V. 2. P. 341-345. (Rus.) 